\title{
Converging structures? Recent regulatory change in bus-based local public transport in Sweden and England
}

\author{
Tom Rye $^{a *}$, Anders Wretstrand ${ }^{\mathrm{a}}$ \\ a Department of Transport and Roads, LTH, Lund University, Sweden; and also K2 Swedish National Knowledge Centre for Public \\ Transport, Lund, Sweden. \\ * Corresponding author.
}

\section{Keywords (up to 8):}

Quality, partnership, contract, regulation, England, Sweden

JEL Codes: R4, R5, H2, H4, L5, L9

\begin{abstract}
This paper compares the regulatory structures that have developed in local bus regulation over the past 20 years in local public transport in Sweden and England outside London, and their impacts. The paper will attempt to assess how far there are similarities in these structures and whether there is evidence of any form of convergence. It does so with a review of the relevant legislation and structures, and their effects, based on the published and grey literature in the two countries. It uses a theory of the regulatory cycle (based on Needham, 1983) to theorise the relative regulatory positions of the two countries. It pays particular attention to the development of types of cooperative or partnership contract between the public and private sectors in local bus transport in the two countries, and assesses the similarities and differences between these two contracts. It concludes that, whilst the two countries may be at different points on the regulatory cycle, and therefore that in regulatory terms these partnership contracts are the result of very different pressures, in fact they are resulting in some similarities, though not in any way a regulatory convergence.
\end{abstract}

\section{Introduction and structure of the paper}

The objective of this paper is to compare the structures that have developed in local bus regulation over the past 20 years in local public transport in Sweden and England outside London. The paper will attempt to assess how far there are similarities in these structures and whether there is evidence of any form of convergence. The analysis will be linked to the theory of the regulatory cycle (Needham, 1983; Gwilliam, 2008) and seek to add nuances to that theory as it applies to the bus industry in these two developed countries.

The structure of the paper is as follows:

- To re-introduce the theory of the regulatory cycle.

- Give a brief re-cap of the British regulatory situation outside London and its impacts.

- To provide some more detailed case studies of the partnerships that have been set up under more recent laws that modify the basic British deregulated model.

- Explain the structure of the Swedish industry prior to the passing of the 2012 law.

- Explain how this has now changed and the new organisations that have been set up as result.

- Challenges and issues that this new structure is throwing up for operators and (public sector) regional public transport organisations in Sweden.

- Present as far as is known the changes that this has so far led to in the pattern of public transport provision "on the ground" in Sweden.

- Draw out the lessons of the British experience for the developing Swedish situation, and vice versa.

- Consider the implications of the experience of these two countries for the regulatory cycle. 
It should be noted that van de Velde and Wallis' (2013) paper has compared the recent British and Swedish situation. There is therefore inevitably some duplication between our paper and theirs. There are also other papers to be presented at Thredbo 2013 that will cover in some detail the Swedish situation. However, this paper nonetheless adds to these papers and to the work of van de Velde and Wallis in various ways:

- It provides explanations of why powers of greater regulation introduced in Britain in 2000 were not widely used.

- It provides more and more detailed case studies of the use of powers introduced in Britain since 2008.

- It argues that there will be tendencies for the new Swedish system to evolve from mixed local and regional towards strategic regional planning and financing models for local public transport that existed prior to 2012, and considers the implications of these changes.

- It provides a comparison of the two systems including on the ground changes in Sweden since 2012.

\section{The theory of the regulatory cycle}

Gwilliam (2008) revisited and discussed Needham's (1983) model of the regulatory cycle. This is shown below. For brevity, the reader is referred to the 2008 paper for a full explanation of the cycle and thus a full explanation is not provided here.

Figure 1 - The regulatory cycle, from Gwilliam (2008), based on Needham (1983)
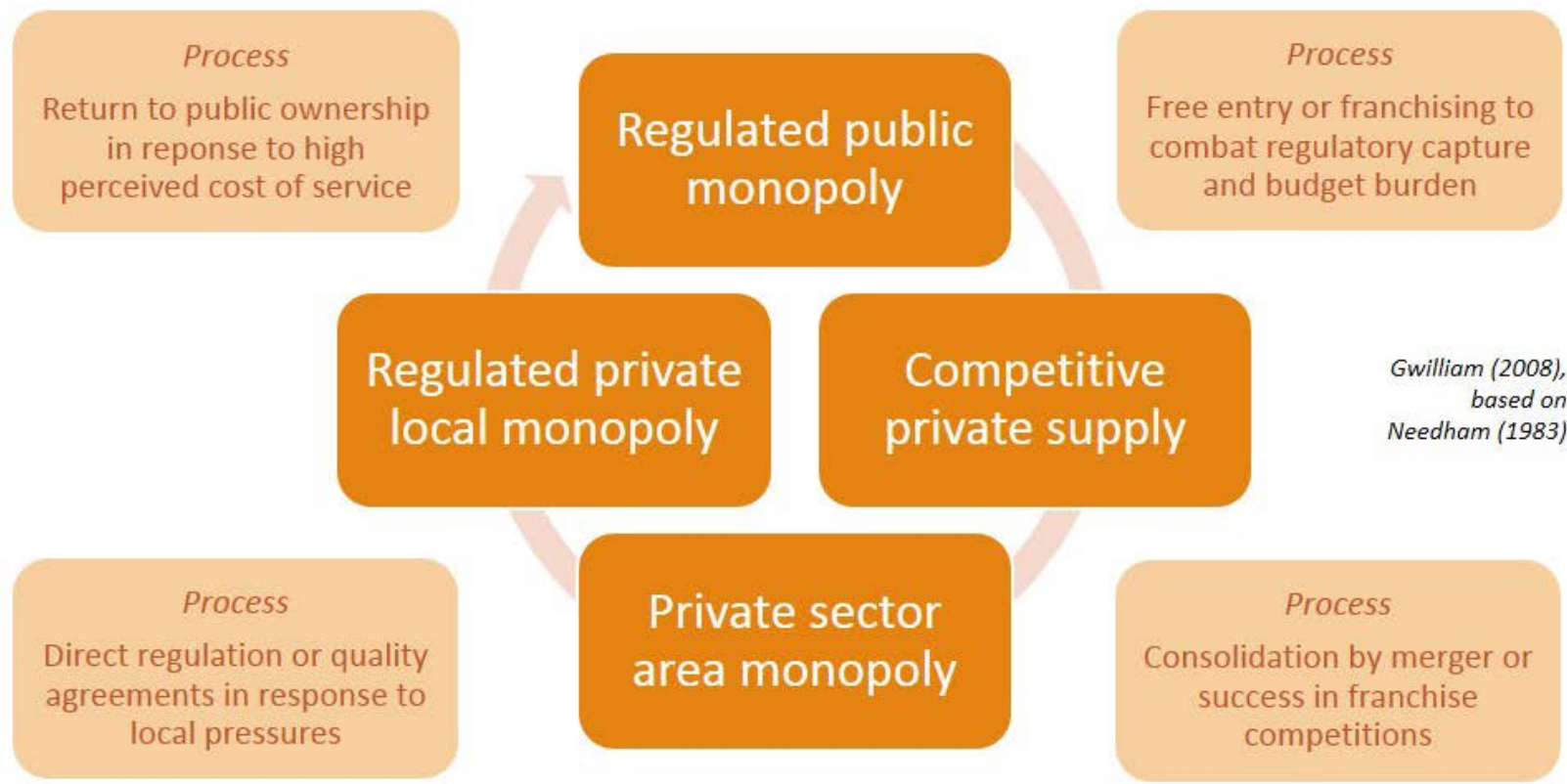

The subsequent sections of the paper will show that, arguably, Great Britain outside London has moved to the situation of private sector area monopoly, but that there are some very limited moves towards the regulated private monopoly situation. Since the 1980s, Sweden has sat somewhere on the right hand side of the graphic but the reforms introduced in 2012 make it rather harder to place and indeed call into question somewhat the "neatness" and uni-directional nature of the cycle, as will be explained later.

\section{Recent developments in bus regulation in Britain outside London}

The basic regulatory framework for local buses in Britain outside London was set up under the 1985 Transport Act and has received much attention in the literature, so only the briefest summary is provided here; the interested reader is referred to Preston (2008) for a much fuller analysis of 
the process, and its effects. The Act replaced a regulated subsidised public monopoly situation with one where any profit-making operator could register and run a bus service, based on the theory that on-road competition amongst many operators would drive down operating costs, improve service quality, cut fares and subsidy, and attract new ridership. The public sector would not intervene in the market but would just provide "socially necessary" services where these were not provided by the market.

Costs and subsidy were indeed reduced significantly, but on-road competition between many small operators was quickly replaced, through merger and acquisition as well as by tacit agreement, with geographical monopolies or duopolies, leading to imperfect fare and service levels. Ridership has continued to fall in all of England outside London (Transport Statistics Great Britain, 2011), although the degree to which this fall has been caused or exacerbated by deregulation is contested.

The first regulatory modification to this situation was introduced in the Transport Act (2000) (or 2001, in Scotland); this was a response to lobbying of the then new Labour (social democrat) government by local authorities of the same party who were dissatisfied with the bus services provided under the 1985 act and with the very limited influence that they had over them. This legislation allowed local transport authorities (municipalities with transport powers) to do the following:

- Require bus operators to provide a minimum level of information about their services, or charge them and provide that information if it was not provided by the operators.

- Require operators to provide a multi-operator integrated ticketing scheme, although not one that provided fares lower than single operator tickets.

- Require operators to enter into a binding Statutory Quality Partnership (SQP) scheme with the local authority to improve the quality of bus services in in a designated area. Quality could cover aspects such as vehicle specifications, infrastructure, cleaning, information, driver training, parking enforcement en route and at stops and so on but, crucially, not service levels/frequencies or fares - these latter remained wholly controlled by operators.

- Implement a Quality Contract, or system of franchised bus services, where SQPs had been tried and market failure could be demonstrated.

The use of the last two powers was to be initiated by the local authority but ultimately approved, before implementation, by the national Department for Transport (DfT) or equivalent in Scotland and Wales.

The first power was used widely, the second not at all to the authors' knowledge (it is unclear whether the City of Nottingham Kangaroo ticket is a result of powers used from the Act, or a voluntary agreement), the third resulted in two SQPs and the fourth was never permitted to be used, although there was some pressure from transport authorities in metropolitan areas to use it. Why were most of these powers so little used? In 2005 the Scottish Parliament Local Government and Transport Committee carried out an inquiry into the use of powers in the 2001 Transport (Scotland) Act. In summary, this report found that local authorities were deterred from using the powers due to:

- A lack of obvious benefits stemming from the use of these powers, over and above voluntary agreements with operators, especially for quality partnerships.

- Greater complexity and risk associated with the use of statutory powers.

- A lack of staff and other resources.

- A strong steer from central government that the power on Quality Contracts was intended to be used only when all other options had been shown not to function.

In addition, operators tended to shy away from entering into statutory agreements for fear that 
these might be judged anti-competitive, since the penalties for anti-competitive behaviour are very large.

Concerned, perhaps, at the lack of take-up of the powers in the $2000 \mathrm{Act}$, the government then passed the Local Transport Act 2008 (applying in England and Wales only). This includes the possibility for a local authority to specify maximum fares and minimum frequencies in a Statutory Quality Partnership - but only if an operator does not make what is called an "admissible objection". This is where the operator can show that the requirement for minimum frequencies or maximum fares in the proposed scheme was either not practicable or not commercially viable (or both) for them to comply with. Operators will therefore tend to support a proposal for a SQP where it is clear that the local market has the potential to grow sufficiently to provide a return on the investment required from them for their participation in the partnership clearly, then, not in every local bus market.

The Act also introduced the Qualifying Agreement (QA), an agreement 'certified' by the Local Transport Authority to permit operators to agree to run services on the same route in a coordinated way, without risking a large fine from the Office for Fair Trading (OFT) for breaking competition law, as was the case prior to the 2008 Act. This has since been used in at least one case, in Oxford, to reduce bus numbers in an environmentally sensitive city centre: where operators previously ran two competing buses, both at the same time and at a 10 minute headway, they now share the market with one bus departing every 7-8 minutes. The Act also permits a Multi-operator Individual Ticket (MIT) agreement to accept one another's tickets, also used in Oxford.

In addition, the Act should make it easier for local authorities to enter into quality contracts. The new process is one where the local authority proposes and consults on the quality contract; a committee chaired by a Senior Traffic Commissioner (a DfT staff member) then reviews the proposal and makes recommendations on it; the local authority then decides how to respond to these recommendations and ultimately whether to implement the scheme. In reviewing the proposal, the committee must consider the scheme's impact in relation to various criteria including "public interest" and "proportionality of adverse impact on [existing] operators". The requirement to demonstrate market failure has been dropped. If a local authority chooses to implement the scheme without regard to the recommendations of the committee, there is a significant risk that operators may appeal the decision to a government tribunal. Current (2013) government policy in England is to neither encourage nor discourage Quality Contracts; still, though, there are none in operation although at the time of writing Tyne and Wear Integrated Transport Authority (Nexus) in the north east of England is investigating how QCs might work in their area (DfT and Nexus, personal communication, July 2013). However, there are now a small number of statutory quality partnerships, and this paper now goes on to review these in a little more detail.

\subsection{Statutory quality partnerships in place in England outside London to date}

It is difficult to be absolutely certain about the total number of SQPs in operation as of July 2013, but sources such as http://www.buspartnership.com (accessed $24^{\text {th }}$ July 2013), van de Velde and Wallis (2013), and individual local authorities' websites indicates that there may be fewer than ten, including two made formed under the powers of the 2000 Transport Act (so prior to 2008). Clearly, then, the statutory quality partnership is not yet a widespread phenomenon, perhaps because of the conditions that one must satisfy if it is not to be subject to appeal by operators.

The existing partnerships (QPs) and their characteristics are detailed in Table 1, below. This information is sourced from the partnership documentation produced by each local authority to define the nature of the partnership. This documentation typically defines:

- The area or route(s) covered by the QP, and the services that must comply with the quality standards defined. 
- The date on which the partnership comes into effect.

- The means by which compliance with the quality standards will be monitored.

- Performance targets (for example, improvements in ridership or journey times) which the QP seeks to achieve, but whose non-achievement does not constitute grounds for noncompliance.

- The service and quality standards that both operator(s) and local authority undertake to meet, and who is responsible for delivering them. These typically cover the following elements and are necessarily specified in detail, since the definition must be precise enough to be capable of being enforced:

o Vehicle emissions and accessibility standards.

o Vehicle maintenance standards, including cleanliness.

o Driver training and quality of driver's customer service.

o Punctuality and reliability, including in some QPs money-back guarantees.

o Limiting the frequency of service changes in order to promote network stability.

o Information on- and off-bus, including real time information.

o Infrastructure - defining the stops, interchanges, bus stations, bus priority on road and at traffic signals that would be provided, and how often these would be maintained.

o For some QPs, fares and service levels.

See Table 1, at the end of the paper, for a summary of the characteristics of each of the QPs for which details were available. It is notable that some scheme documentation is far more detailed in specifying its requirements than others (compare for example that for Manchester A6 corridor with that for the North Sheffield corridor) and in some there are no details of how monitoring of compliance with the scheme is to be carried out.

Particularly interesting for the purposes of this paper are those partnerships that involve agreements to limit services or access to stops, or to regulate fares and frequencies. On the A6 corridor in Greater Manchester, all services operating above a minimum frequency are subject to the quality standards of the QP, but only 3 core services have minimum service requirements. These essentially guarantee the times of first and last buses and frequencies in the early morning, in both peaks, in the interpeak and evening. In this case, on a core route in a major conurbation, the minimum service is 6 buses per hour (bph) between 0510 and 2330 on weekdays. Nottingham's QP regulates access to city centre stop infrastructure in order to reduce bus congestion in an environmentally sensitive area.

Only 3 of the QPs include actions to regulate fares in any way. In Merseyside and Birmingham this is limited to operators offering tickets that allow interchange without a fares penalty (Birmingham) and accepting the other main operator's multi-journey tickets (Merseyside). In Greater Bristol under the heading of one QP, so far schemes have been made covering 7 of at least 10 planned QP routes. All of these include a requirement on maximum fares and a maximum fares increase related to a bus industry cost index. This is in an area where adult single fares are expensive: in 2013, in the order of €2 for a 1-2 km trip, €4 for a $6 \mathrm{~km}$ trip and €6 for a $15 \mathrm{~km}$ trip. But this QP is a first for the British bus industry outside London because of its explicit mechanism to limit fare increases.

To summarise these various QPs, they all have the objective to improve service quality and therefore implicitly or explicitly to raise patronage, and all bar two are very recent. They then fall into two categories: route QPs, and city centre QPs; the latter also seek to reduce bus congestion and regulate access to stop infrastructure. Almost all designate "Core" or higher frequency services, which normally have to meet the quality standards of the QP more quickly than "non-core" services. Only a minority of the QPs reviewed currently use the "admissible objection" powers related to fares and frequencies. In terms of the regulatory cycle, we can see them as local regulation or quality agreements to try to deal with some of the perceived 
problems of a private monopoly of bus provision in the areas concerned - so the bottom left hand box in Figure 1.

Primary interview research was carried out in late summer 2013 with the public authorities who were responsible for five of the eight partnerships listed in Table 1. Attempts were also made to contact bus operators involved in the partnerships but this proved impossible as repeated emails and phone calls were unanswered; this is clearly a problem in terms of the presentation of these results, and further work needs to be carried out to understand the operators' motivations in signing up to these partnerships that contain what might be seen as quite onerous conditions. The main purpose of the interviews was to establish the current status of the statutory partnerships and what had occurred since they had been implemented. Key results are summarised in Table 2, below; the partnerships are anonymised.

Table 2 - Results of statutory quality partnerships, as of September 2013

\begin{tabular}{|c|c|c|c|c|}
\hline & SQPS1 & SQPS2 & SQPS3 & SQPS4 \\
\hline Results & $\begin{array}{l}\text { Small increase in } \\
\text { patronage and } \\
\text { reliability } \\
\text { Improved vehicle } \\
\text { quality }\end{array}$ & $\begin{array}{l}\text { Cut journey times } \\
\text { Improved vehicle } \\
\text { quality } \\
\text { Improved network }\end{array}$ & $\begin{array}{l}\text { 1\% increase in } \\
\text { passengers in first } \\
\text { year (decline } \\
\text { previously) } \\
\text { Improved vehicle } \\
\text { quality }\end{array}$ & $\begin{array}{l}17 \% \text { increase in } \\
\text { main operator's } \\
\text { passengers over } 4 \\
\text { years }\end{array}$ \\
\hline Problems & $\begin{array}{l}\text { Initial opposition } \\
\text { from operator } \\
\text { Operator forced to } \\
\text { run sub-standard } \\
\text { buses at one point }\end{array}$ & $\begin{array}{l}\text { Lack of political } \\
\text { buy-in } \\
\text { Still some } \\
\text { duplicative } \\
\text { competition }\end{array}$ & $\begin{array}{l}\text { Legal process } \\
\text { lengthy - needed } \\
\text { even for minor } \\
\text { changes to scheme }\end{array}$ & $\begin{array}{l}\text { Initial opposition } \\
\text { from operator } \\
\text { Few resources to } \\
\text { monitor }\end{array}$ \\
\hline $\begin{array}{l}\text { Benefits as } \\
\text { expected? }\end{array}$ & $\begin{array}{l}\text { Largely; also } \\
\text { stopped politicians } \\
\text { removing bus } \\
\text { priority }\end{array}$ & Yes & $\begin{array}{l}\text { Significantly more - } \\
\text { levered in extra } \\
\text { investment and } \\
\text { service }\end{array}$ & $\begin{array}{l}\text { Largely as } \\
\text { expected }\end{array}$ \\
\hline $\begin{array}{l}\text { More SQPS } \\
\text { planned? }\end{array}$ & $\begin{array}{l}\text { No - seen as one- } \\
\text { off infrastructure } \\
\text { investment } \\
\text { Future seen as } \\
\text { VPAs }\end{array}$ & $\begin{array}{l}\text { No; this SQP is to } \\
\text { deal with a very } \\
\text { specific problem } \\
\text { location }\end{array}$ & $\begin{array}{l}\text { Yes, at least seven } \\
\text { in metropolitan area }\end{array}$ & $\begin{array}{l}\text { Yes, at least three } \\
\text { more routes }\end{array}$ \\
\hline
\end{tabular}

The SQPs appear from this small sample to be achieving what they were intended to do, with some unexpected benefits also, such as "locking in" the authority to the provision of bus priority measures, when there was political desire to remove such measures after changes in political control. However, authorities differed rather markedly in their plans for more SQPS. One major metropolitan area had no plans for further measures, rather seeing the other powers related to service coordination, joint ticketing plus voluntary partnerships between operators and authorities to be of much greater long term potential. They took this view because the 2000 and 2008 Transport Acts require authorities to provide new infrastructure as part of a SQPs and, as they put it, "once this [infrastructure] card has been played, it cannot be played again". Other major authorities still have plans for further SQP schemes, as they feel that there are still corridors where new infrastructure is required.

One important question posed, which relates to the regulatory cycle, was why, in the view of the authorities, had bus operators "submitted" to the additional regulatory burden of a statutory as opposed to voluntary quality partnership. In most cases this was explained as the result of the possibility of stricter regulation (quality contracts, or franchising) if operators chose not to participate in SQPs and other "softer" forms of regulation. It was however noted that such "softer" forms of regulation can only be successfully implemented on relatively profitable routes (or in city centres to which operators need access), where it is worth an operator's while to invest; overly stringent quality standards imposed within an SQPs on less profitable routes would simply lead 
the operator to stop running the route. Finally, in terms of monitoring compliance, it was clear that for some authorities at least, resources were not available for this, so they were reliant on the bus operators' honesty in keeping to the terms of the SQPS.

\section{Trends and situation in Sweden}

\subsection{Historical development}

After WW2 several societal changes and regulatory measures occurred in Sweden, altering the roles and organisational structure of public transport. Main railways and several bus operators were nationalised, and urbanisation and automobility expanded rapidly. Local public transport, now with bus route networks not trams, could no longer could cover its full costs from tickets. Regional bus routes were often concession contracts with either state or privately owned operators, and municipalities and regions felt that they no longer would "subsidize government". Also, there was a poor link between local and regional supply, because of two separate organisational systems. Private sector area monopoly transferred to public monopolies.

Referring to Gwilliam (2008), the next shift could also be described as a return to public ownership in response to high perceived cost of service, though it also included a shift from national influence to local and regional responsibility. These were first seen in the organisational solutions in Stockholm in the 1960s that initiated the work towards what has later been characterized as "the Scandinavian model" (van der Velde and Wallis, 2013). In 1967, AB Storstockholms Lokaltrafik was formed as the first local and regional public transport authority in Sweden [THM-TrafikHuvudMan].

Later in the mid-70s, on the west coast, the city of Gothenburg united with the surrounding municipalities to form the Gothenburg regional THM. National regulatory reform in 1979 created such THM in all 21 Swedish counties, responsible for providing local and regional public transport. Still, some regional operators (private as well as state owned) had concessions and the THM had to contract them for socially necessary services. Therefore, in 1989, all regional concessions were transferred to the THMs, and they could then start the competitive tendering (CT) process.

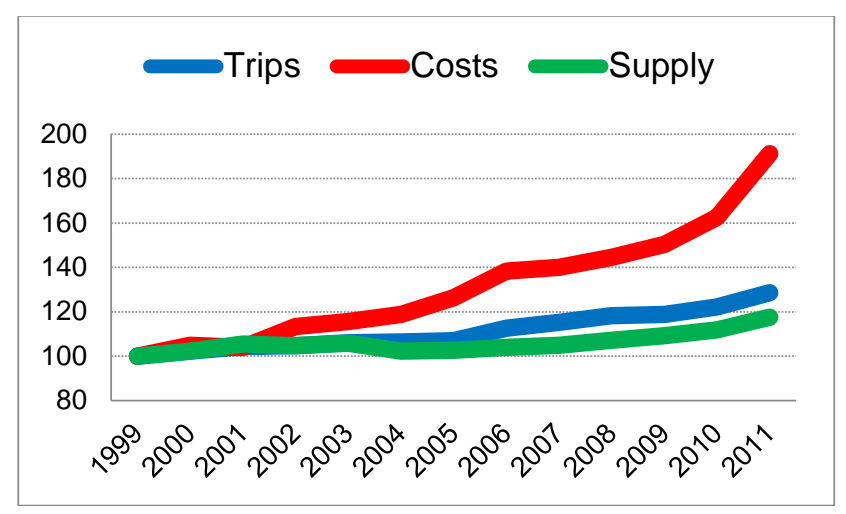

Figure 2. Relative development of ridership, costs and supply in Sweden (data from TRAFA, 2011)

During the 1990s, the CT process was seen as a step forward. "Competition off-the-road" (van der Velde et al., 2008) resulted in better supply for similar or lower costs, allowing for THMs to focus on better vehicle quality as well as new ticketing and information systems. However, as stated by Westin (2009), the resulting efficiency and network effects gradually decayed. As depicted in Figure 2, even though total ridership seems to increase after year 2005, costs increased faster. At the same time, almost all operators "competing for the road" did not benefit from the increasing ridership. On the contrary, they have posted losses (see Table 3).

Table 3. Economic status, five largest operators in Sweden (Source: Annual reports 2010) 


\begin{tabular}{lrrrrl}
\hline Company & $\begin{array}{r}\text { Turnover } \\
\text { KSEK }\end{array}$ & $\begin{array}{r}\text { Result } \\
\text { KSEK }\end{array}$ & $\begin{array}{r}\text { Margin } \\
\text { \% }\end{array}$ & Trend & Owners \\
\hline Nobina (2011) & 7050 & -230 & $-3,3$ & Neg. & Banks \\
Keolis & 3040 & -19 & $-0,6$ & Neg. & SNCF \\
Veolia & 2750 & -81 & $-2,9$ & Neg. & Veolia \\
Arriva & 1150 & -109 & $-9,5$ & Neg. & DB \\
Nettbuss & 930 & -100 & $-10,8$ & Neg. & NSB \\
\hline Sum & $\mathbf{1 4} 920$ & -539 & $-\mathbf{3 , 6}$ & & \\
\hline
\end{tabular}

\subsection{Towards regulated deregulation}

Several public stakeholders as well as the industry were dissatisfied with the trends of stagnation, lack of innovation and the standard gross cost contract that characterized the Swedish public transport market. A "vitalising injection" (Westin, 2009) was thus needed, and the proposal made by the government commissioner Ulf Lundin (SOU, 2009) was intended to be just that: focus on the passenger perspective through deregulation and market initiatives. However, during the preparation of the proposal and when it was sent out to stakeholders for consultation, it received varied feedback. Small and mid-sized bus operators welcomed the possibility of entering the market on a new basis. Some municipalities who were dissatisfied with their local THM saw the proposal as a way to dissolve the current hegemony to be able to develop their local public transport. THMs and large operators were however more opposed. Van de Velde and Wallis (2013) have already described the proposal details, and van de Velde also delivered an appendix to the proposal to place the deregulation ideas into an international perspective. According to the Needham model of the regulatory cycle, the "Lundin approach" illustrates the transfer from public monopoly to a kind of "free entry" to combat regulatory capture and budget burdens, in search for market solutions for innovation and customeroriented measures.

Eventually, as a result of the criticism, the proposal was modified before becoming law as Prop. 2009/10:200. However, one key proposal was retained, namely to place emphasis on the strategic level (earlier described as a "Transport Statement", now a Regional Transport Supply Plan (RTSP)). The RTSP was to be developed by the new legal organisation: the Regional Public Transport Authority [RKM-Regional KollektivTrafikMyndighet]. The RKM were to replace the THM, now as public authorities instead of the THM which commonly acted as public companies with shareholders (who were the municipalities and regions within the county).

As it now stands, the formation of the RKM authority has resulted in one authority in each of the 21 counties. Also, some counties have shifted means of public funding, and municipalities have transferred a part (corresponding to the amount of PT funding earlier) of their local tax income to the county council. Aspects of this regulatory shift will be described further below.

\subsection{Structural change in Sweden}

The characteristics of the Swedish public transport market up to 2012 was CT, gross cost contracts with or without some quality incentives, and contract lengths up to 8-10 years. A few large leading operators were created through mergers led by larger European companies. uring the 90's, the gross cost contract model was developed towards increased use of quality incentives. Few, if any, contained patronage incentives. Operators still had less or no influence over supplies and fares. However, early in the 90's, an interesting net cost contract partnership was developed in the city of Helsingborg. The commercial operator kept fare box plus fixed remuneration from the city, and could decide ticket price and fare structure, as well as routes, timetables and vehicles. They also partnered in infrastructure development investments with the city that aimed at operation efficiency. Eventually, the net cost model was dropped, mostly because of emerging tensions between the city and regional public transport authority, the latter striving for a more regional planning approach, and also because of the poor interest from the 
operator management side. The "Scandinavian model" had created operators that were experts on cost control, but less focused (thus lacking the skill) on revenues, sales and marketing.

Fare levels and structures have been politically decided since the THM model was developed, and ticket incomes are kept by the public local and regional bodies. Around $50 \%$ of the operating costs have been covered by ticket income. THMs have been owned by the county and municipalities together on a 50/50 basis. In terms of how subsidy is shared out between operating areas - and therefore type of route - four models have existed (Figure 3), and the three major ones will be described below.

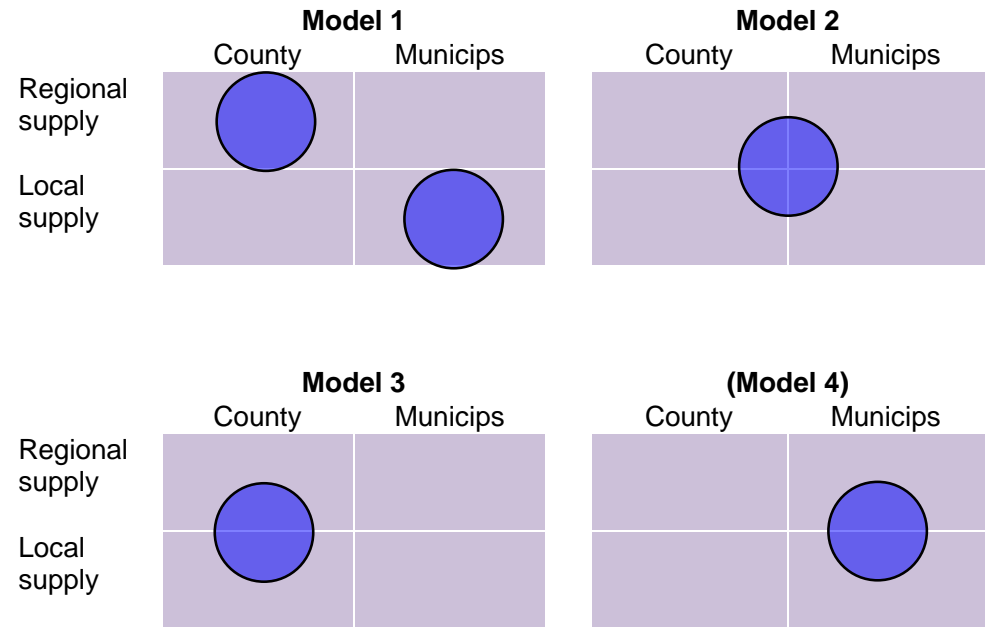

\section{Figure 3. Subsidy models in Sweden, division between local and regional transport}

Model 1 is based on $50 \%$ on local "production", i.e. the number of vehicle kilometres produced in each municipality, with the other $50 \%$ are covered by the county. The model is simple.

"Profitable" routes subsidise the "unprofitable" ones. However, the model has obvious drawbacks. It tends to preserve the current situation, e.g. increased supply in one municipality will affect the costs in other municipalities. Model 2 was introduced to deal with this problem, and is common across Swedish regions. The advantage is a stronger focus on regional transport. Routes are being classified according to local or regional function, and clarifies the roles of involved authorities. Finally, model 3 means shifting resources to the regional county level. Stockholm could be said to fit this model since the formation of SL in the mid-60s, but the most significant example of model 3 could be found in South Sweden.

Skånetrafiken, the former THM in the county of Scania [Skåne], was formed in 1998 through the merger of two counties. Scania was given, experimentally, extended responsibilities for regional development (e.g., infrastructure, public transport and culture). Through an extensive launch of regional rail, the Öresund Bridge, a strong focus on main lines (local and regional trunk routes) and strategies, Skånetrafiken has managed to double ridership, and aims to repeat it. Model 3 and the taxation shift allow Skånetrafiken to optimise resource allocation. In order to avoid rural areas suffering from the trunk route strategies, all municipalities in the region have a time-limited contractual agreement with Skånetrafiken, which then needs to be renegotiated for the next period. By the end of the 90s, some municipalities feared that the new model would result in reduced supply. However, by adopting a fare policy with low fare levels on longer trips and slightly increased fares on shorter (urban and peri-urban) these fears have not been realised.

Even though there has been a legal regulatory change through the 2012 public transport law, the models presented will continue to exist. At present there are indications of political discussions going on, that will change the arrangements in some regions. As an effect of the experienced gained of model 3 in Scania, other RKM will most likely follow and Västra Götaland (a county with 49 municipalities including Gothenburg) has already made this change. It should 
be noted, however, that the evident attractiveness of this model is based on the situation when ridership and supply increased substantially. It therefore remains to be seen whether the seeming consensus will continue through times when regions/counties will have to conduct economic reforms and cost cuts. Decisions of supply cuts are likely to hit remote areas with low cost recovery, areas and municipalities already challenged by the urbanisation processes and a remaining population that is ageing.

\subsection{Challenges and issues that this new structure is throwing up for operators and RKM in Sweden}

During the last years of some regulatory change, all stakeholders in the Swedish public transport sector have emphasised the need for deepened collaboration (van de Velde and Wallis, 2013): between local and regional owners (politics), public transport authorities, city planners, local traffic administration, state road and rail (Swedish Transport Authority), industry and not the least private operators (train, tram, bus, and taxi). A regulatory framework and existing contracts alone cannot solve the problems various actors face while planning and/or operating services. Therefore, the so-called "Swedish Doubling Project" (x2) aims to foster a vision of partner co-operation focused on doubling ridership and market share by the year 2020.

One outcome of the Doubling Project is the proposal of contract models, jointly developed by authority and operator representatives. These are suggested to be adopted when existing contracts end, and aim to support the regulatory shift from the gross cost contract capture that has prevailed in Sweden over the last 20 years. Whether this shift, call it paradigm shift or not, results only from experience, or was also triggered by the "governmental threat" presented by Lundin (SOU, 2009) is difficult to say. Nevertheless, the pressure on the sector that came with the Lundin proposal may have accelerated the process.

Table 4 gives a brief overview of contract types that exist and are planned to be realised. Further descriptions of previous contract principles have been described in several reports and research papers, but the incentives and remunerations in the new contract models are interesting. There is a shift towards the concession principle, leaving the operator with enhanced commercial risk. In some cases (Type E) the operator will, at least partly, keep and have influence over the ticket income and fares. Other contracts have a strong patronage incentive, but fare decisions will still be taken by the authority (which will also retain the revenue).

Table 4. Examples of operating contract models in Sweden, main principles

\begin{tabular}{|c|c|c|c|c|c|}
\hline & Type & Incentives & Remuneration & Ticket box & Exist. \\
\hline A & $\begin{array}{l}\text { GCC } \\
\text { (Gross cost contract) }\end{array}$ & No (only malus) & $\begin{array}{l}\text { Per vehicle and } \\
\mathrm{km}\end{array}$ & No & $\sim 1990-$ \\
\hline B & $\mathrm{GCC}+$ & Quality* & $\begin{array}{l}\text { Per vehicle and } \\
\mathrm{km}\end{array}$ & No & 〜1995 - \\
\hline C & GCC++ & $\begin{array}{l}\text { Quality*, }^{\star} \\
\text { performance }\end{array}$ & $\begin{array}{l}\text { Per vehicle and } \\
\mathrm{km}\end{array}$ & No & $\sim 2005$ - \\
\hline D & Concession & Malus* & Per passenger & No & 〜2014 - \\
\hline$E$ & Concession+ & No & & $Y^{*} s^{\star \star \star}$ & 〜2014 - \\
\hline$F$ & Net cost contract & varying & Fixed amount & Yes & 1990 -, rare \\
\hline
\end{tabular}

\subsection{Evidence of new deregulated routes in Sweden}

The effects so far from the Swedish "regulated deregulation" (van de Velde and Wallis, 2013) have been quite limited. According to Trafikanalys (Traffic Analysis, the governmental authority for monitoring, analysing and evaluating proposed and current transport policies and measures), reasons are 
1. Conflicts between commercial services and publicly subsidized services

2. The formation of new RKM authorities with slightly unclear roles

3. That the RKMs' regional transport supply programs are first versions, in need of some fine-tuning

The first reason was already discussed in SOU (2009). The proposal author tried to avoid this by first seeking market initiatives, and then "fill up" with publicly funded supply. Also, he foresaw that litigation might result if public monopolies are seen to try to displace the private enterprises. The current law allows a deregulated operator the opportunity to appeal, if there is evidence that the supply according to program could be operated without subsidy, or if access to terminals and hubs is made difficult. However, this will inevitably place many companies in a slightly difficult position, since they in theory might be competing with themselves (as most are likely to be operating under the contracted regime also).

Inscribed in these conflicts and unclear roles, the operators try to navigate and identify new commercial concepts and transport offers. So far, the results according to Trafa are: one city bus network ("commercially" operated by the municipal company), 6 bus routes, 4 tourist bus routes, 2 boat lines, 2 temporary bus routes, 3 fixed and one demand-responsive airport route.

\subsection{Partnership models in Sweden}

Both in the pre- and post-deregulation world in Sweden, partnership contracts have developed in a few areas, and these show some similarities to their British counterparts, but with the main difference that they operate in a context of competitively tendered gross cross contracts, not market provision.

These do not contain formalized contracts between partners, apart from the tendered services of course, but are rather a Memoranda of Understanding character (TFK, 2007). These "agreements" involve the THM (today RKM), the operator(s) and the city. Below, two examples are described briefly (see further in TFK, 2007, Trivector, 2009). Table 5 shows an overview of developments in ridership between 2005 and 2010. (Karlstad is also included as it is a city with a close operator-city partnership. Further details will be presented at the conference.)

\section{Table 5 - performance of local bus networks in Swedish cities with partnership} "contracts"

\begin{tabular}{lllll}
\hline City & Year & Helsingborg & Gävle & Karlstad \\
\hline Inhabitants & 2010 & 98000 & 72000 & 62000 \\
Routes & & 17 & 11 & 22 \\
Best headway, mins. & & 6 & 10 & 10 \\
\hline Trips & 2005 & 7970000 & 5108000 & 4016000 \\
& 2010 & 11612778 & 6057329 & 5517782 \\
& $\Delta$ & $46 \%$ & $19 \%$ & $37 \%$ \\
\hline Trips / inh. & 2010 & 118 & 84 & 89 \\
\hline Income / trip, SEK & 2005 & 7,64 & 9,32 & 8,85 \\
& 2010 & 8,74 & 10,42 & 8,58 \\
& $\Delta$ & $14 \%$ & $12 \%$ & $-3 \%$ \\
\hline Subsidy / trip, SEK & 2005 & 7,57 & 5,31 & 9,21 \\
& 2010 & 8,13 & 8,54 & 12,61 \\
& $\Delta$ & $7 \%$ & $61 \%$ & $37 \%$ \\
\hline Trips / veh.km & 2010 & 43 & 34 & 29 \\
Trips / veh.hour & & 2 & 2 & 1 \\
\hline
\end{tabular}

\subsubsection{Helsingborg}


The City of Helsingborg is situated in the south Swedish county of Scania. Skånetrafiken (THM/RKM) and the operator Arriva (owned by Deutsche Bahn) formulated a vision (Bussvision Helsingborg) for developing the urban public transport. Clear and measurable aims were defined for various areas, such as increased ridership and customer satisfaction. Skånetrafiken is responsible for planning the network, timetables (but in joint discussion with the others) and the efficient linkage to regional services. The city administration is responsible for infrastructure and is the operator for daily operations. The result is a high increase of ridership, although the subsidy increase per trip is quite moderate (Table 5). The operator is remunerated according a standard GCC plus quality incentives according to an annual customer satisfaction survey, and a very small element linked to ridership increase.

\subsubsection{Gävle}

The City of Gävle is situated in the county of Gävleborg (north of Stockholm). Their basic contract is Model 2 (as mentioned earlier), also sometimes called "the Gävle model", because of their early identification of the drawbacks of Model 1. As a result of their work, Model 2 has implemented in many Swedish counties. In Gävle there is a similar setup as in Helsingborg. MoUs and strategic, steering documents act as guidelines for better services and for future Transit Oriented Development. Based on a standard GCC, the operator's (Swebus/Nobina) incentives actually have benefited from a 50/50 split of ticket revenues, with reduced remunerations related to no. of buses and vehicle kilometres.

\subsubsection{Reflections on these recent trends in cooperative "contracts" in Sweden}

The examples from and experiences gained in Helsingborg and Gävle have served as good examples while suggesting new CT business models for partnership in "The Doubling project". Especially Helsingborg with its ridership increase, but also the revitalisation of the public transport in the City of Karlstad, present some evidence that partnership and co-operation should be characterizing Swedish urban public transport in the future.

However, both contracts described above have ended. Nobina were hoping to continue and win the next 10-year period in Gävle. However, there was another contractor that came in with the winning bid. The contract design had changed slightly, and the operator now has even larger influence over supply and also fares. Interestingly enough, they report a passenger increase of $17 \%$ the first year, which calls for a more thorough evaluation. The city contract loss in 2011 made the operator Nobina terminate a large ongoing regional contract after only two years (not the planned 2019), due to poor returns. This contract was taken over by KR-Trafik, the same operator that won the city routes.

In Helsingborg, the operator Arriva had been struggling as best they could to show positive numbers and gain incomes through the contract incentives. However, at the next tender in 2012, Arriva lost and Nobina won with the most attractive bid (financially as well as the proposed ideas for quality enhancement).

To work in a three-part cooperation is challenging, not the least for the operator. This means a slightly new way of organising the operation administration and the need for analysis and evaluation skills are salient. Previously, there have only been a very strong focus on cost management from the operator side, and changes in patronage thus becomes more or less irrelevant. Furthermore, decisions and city traffic and land-use planning propositions need to analysed from a commercial perspective - which alternatives are better in terms of operation and ridership - and such analyses require analytical tools and even modelling competences. Finally, since the transport authorities (and the local and regional politicians) have the final decisions on fare principles and levels, operators should be able to calculate effects of proposed fare changes in order to predict future revenue effects. In GCC, the public bodies take the commercial risk, but it is also possible for them to adjust the supply if needed, and they are 
arguably better placed than an operator (certainly an independent) to absorb risks caused by changes in framework conditions such as changes in fuel prices and changes in population in an area. This is not possible for an operator to do within an on-going contract period. The slight tendency for operators to lose their cooperation contracts at the time of the next tender indicates that the costs and risks have been underestimated at the time of bid preparation. A better basis for reward of operators in this kind of cooperation contract might therefore be quality measures rather than ridership and revenue itself.

\section{Discussion and conclusions}

The introduction to this paper promised that we would draw out the parallels between the English and Swedish situations with regard to bus regulation. Here, at the point of the discussion and conclusions, this begs the question: are there any parallels? At first sight, in spite of the possibility of deregulation held out by the 2012 Act in Sweden, the situations seem rather different: in Sweden the public sector remains firmly in control in a system that is still over $99 \%$ based on competitively tendered contracts, and that is on average $50 \%$ subsidised, and where politicians make decisions about fare and often service levels, but where a very small number of operators compete for these contracts. This would Sweden, currently, around the point of "private sector area monopoly" in the cycle - but in fact its situation would be better described if the category of "public sector area monopoly" existed within the regulatory cycle as defined by Gwilliam (see also end of next paragraph, below).

In Britain, private operators, running with public subsidy awarded in a very different way to Sweden, continue to make most strategic, tactical and operational decisions. Both countries are therefore at the same point on the regulatory cycle, albeit in different regulatory contexts. It is difficult also to see that the regulatory cycle describes the history of the Swedish situation as well as it does the British; and whilst this paper shows that local partnerships have developed in Sweden as well as in Britain, the difference with respect to the regulatory cycle is that partnerships in Sweden do not impose additional regulation on operators, whereas they do in Britain. It is difficult to see how Sweden could move from where it is now on the cycle "forward" to regulated private monopoly; possible next moves might be back to fully competitive supply, or forward to regulated public monopoly. As argued at the beginning of the paper, this calls into question the relevance of the cycle to an analysis of the Swedish situation.

When we consider recent regulatory changes in the two countries, some of the intervention permitted under more recent British legislation is aimed precisely at bringing greater public sector influence into a market perceived to be overly-controlled by private sector monopolies; whilst the changes in contracts in Sweden, and the threat of some market-led activity, have been driven because of dissatisfaction with a sector perceived to be over-dominated by the public sector and with little autonomy for operators.

Similarities so start to emerge when we start to look at the partnership models that have to a very limited extent sprung up in cities in both England and Sweden. The motivation for these is similar: a desire on the part of both public and private sectors to grow the bus market. Many of the measures implemented are also similar and, critically, involve those who provide the bus infrastructure, not just those who operate and finance public transport. Whilst the effects on ridership of England's statutory quality partnerships are not yet known, it was clear that the voluntary partnerships that preceded them achieved patronage increases not dissimilar to those seen in the Swedish cities in Table 5. Finally, from Bristol's Quality Partnership in England, we see an operator relinquishing some autonomy on key issues of service frequency and fares, yet still entering into partnership with the local authority, as operators in Gävle and Helsingborg in Sweden have done. So, if more statutory QPs continue to develop in England where operators relinquish some autonomy whilst working with their local public sector partners to increase ridership, and more local partnerships develop in Sweden in the context of new contract types 
where operators have more autonomy over service levels and perhaps even fares, then it is not so far-fetched to argue that there is some convergence, in spite of the two very different regulatory contexts.

\section{Reference list}

Bussvision Helsingborg. At present, only a Swedish description exist, since the original web page is under revision, http://www.svenskkollektivtrafik.se/fordubbling/godaexempel/TidigareGoda-Exempel-/Bussvision-Helsingborg/, [retrieved 2013-07-23]

CPT, PTEG and ATCO (2013) Bus quality partnerships - a toolkit for local transport authorities and operators. At http://www.buspartnership.com/, accessed 25/07/13

Gwilliam, K. (2008) Bus transport: Is there a regulatory cycle? Transportation Research Part A 42 (2008) 1183-1194

SOU (2009). En ny kollektivtrafiklag - Delbetänkande av Utredningen om en ny kollektivtrafiklag. [A new public transport law -...] SOU 2009:39. Stockholm: Statens Offentliga Utredningar.

TFK (2007) Trepartsavtal och verksamhetsstyrning. [Three-part agreements and performance management]. TFK rapport 2007:3, Stockholm.

Trafa. Trafikanalys www.trafa.se/marknadsoppning, [retrieved 2013-07-23]

Trivector (2009). Hvordan får man bilister til at bruge kollektiv transport? [How to convince car users to use public transport?]. Trivector Rapport 2009:15, Lund.

van de Velde, D.M., Beck, A., Van Elburg, J.-C., Terschüren, K.-H. (2008). Contracting in urban public transport, European Commission, Brussels, 123 pp.

van de Velde, D.M., Wallis, I. (2013). 'Regulated deregulation' of local bus services - An appraisal of international developments. Research in Transportation Economics 39, 21-33.

Westin, P. (2009). Review of public transport in Sweden: implementation on the passenger rail market and plans for the local public transport market. In: van de Velde, D. M., Veeneman, W. (Eds.), Proceedings of the 11th international conference on competition and ownership in land passenger transport. Delft: Next Generation Infrastructures Foundation, Delft (The Netherlands), 20-25 September 2009, Plenary paper.

x2. The Swedish Doubling Project, http://www.svenskkollektivtrafik.se/fordubbling/Engelska/, [retrieved 2013-07-23]

Needham, D (1983) The Economics and Politics of Regulation: a Behavioural Approach. Little Brown and Company, Boston. 
Table 1 - Comparison of existing Statutory Quality Partnerships known to authors, 2013 - main source is www.busqualitypartnership.com

\begin{tabular}{|c|c|c|c|c|c|c|c|}
\hline Name & Barnsley & Birmingham & Bristol & Gtr Manchester & Merseyside & Nottingham & Sheffield \\
\hline Location & $\begin{array}{l}\text { Barnsley, S } \\
\text { Yorkshire }\end{array}$ & $\begin{array}{l}\text { Birmingham city } \\
\text { centre }\end{array}$ & $\begin{array}{l}\text { Greater Bristol } \\
\text { area }\end{array}$ & $\begin{array}{l}\text { A6,Southeast } \\
\text { Manchester }\end{array}$ & East Liverpool & $\begin{array}{l}\text { Central } \\
\text { Nottingham }\end{array}$ & $\begin{array}{l}\text { N Sheffield, } \\
\text { Barnsley Rd }\end{array}$ \\
\hline Authority making scheme & $\begin{array}{l}\text { South Yorks ITA, } \\
\text { Barnsley Council }\end{array}$ & $\begin{array}{l}\text { West Midlands } \\
\text { ITA, Birming-ham } \\
\text { Council }\end{array}$ & Relevant council & $\begin{array}{l}\text { Led by Gtr } \\
\text { Manchester } \\
\text { Combined } \\
\text { Authority }\end{array}$ & $\begin{array}{l}\text { Merseyside ITA, } \\
\text { Liverpool City } \\
\text { Council }\end{array}$ & $\begin{array}{l}\text { Nottingham City } \\
\text { Council }\end{array}$ & $\begin{array}{l}\text { South Yorks PTE } \\
\text { Sheffield Council }\end{array}$ \\
\hline Main objectives & $\begin{array}{l}\text { Increase pax thru } \\
\text { better quality and } \\
\text { reliability }\end{array}$ & $\begin{array}{l}\text { Improve air } \\
\text { quality, reduce } \\
\text { bus congestion }\end{array}$ & $\begin{array}{l}\text { Improve quality, } \\
\text { regulate fares, } \\
\text { frequencies }\end{array}$ & $\begin{array}{l}\text { Improved quality } \\
\text { and reliability of } \\
\text { service }\end{array}$ & $\begin{array}{l}\text { Increase } \\
\text { passengers } \\
\text { through better } \\
\text { quality }\end{array}$ & $\begin{array}{l}\text { Increase bus } \\
\text { mode share, } \\
\text { reduce bus } \\
\text { congestion }\end{array}$ & $\begin{array}{l}\text { Increase pax thru } \\
\text { better quality and } \\
\text { reliability }\end{array}$ \\
\hline In force since & 2010 & 2012 & 2011 & 2012 & 2011 & 2010 & 2006 \\
\hline Route or area & Both & Area & Route & Route & Route & Area & Route \\
\hline Approximate scale geographically & $\begin{array}{l}\text { Town centre and } \\
5 \mathrm{~km} \text { route }\end{array}$ & $\begin{array}{l}\text { City centre } 3 \mathrm{~km} \\
\text { by } 3 \mathrm{~km}\end{array}$ & $\begin{array}{l}7 \text { Routes of } 8-17 \\
\mathrm{~km}\end{array}$ & $16 \mathrm{~km}$ & $9 \mathrm{~km}$ & $\begin{array}{l}\text { City centre, } 2 \mathrm{~km} \\
\text { by } 2 \mathrm{~km}\end{array}$ & $7 \mathrm{~km}$ \\
\hline Services and frequencies & $\begin{array}{l}11 \text { core most at } 6 \\
\text { bph }\end{array}$ & $\begin{array}{l}\text { C. } 80 \text { core, at } 3-6 \\
\text { bph }\end{array}$ & $\begin{array}{l}\text { Varies, from } 3 \text { to } \\
8 \mathrm{bph}\end{array}$ & $\begin{array}{l}3 \text { core, combined } \\
15 \text { bph }\end{array}$ & $\begin{array}{l}4 \text { core combined } \\
20 \text { bph }\end{array}$ & $\begin{array}{l}36 \text { core all at } 4-6 \\
\text { bph }\end{array}$ & $\begin{array}{l}8 \text { services each } \\
\text { at } 6 \text { bph }\end{array}$ \\
\hline Number of operators affected & One & 18 & Two main & One main & Two main & Two main & Two main \\
\hline $\begin{array}{l}\text { Clear how monitoring to be carried } \\
\text { out? }\end{array}$ & Yes, ops and ITA & Yes, ops and ITA & $\begin{array}{l}\text { Yes, ops and } \\
\text { councils }\end{array}$ & No & No & $\begin{array}{l}\text { Yes, ops and City } \\
\text { Council }\end{array}$ & $\begin{array}{l}\text { Yes, ops and } \\
\text { PTE (now ITA) }\end{array}$ \\
\hline \multicolumn{8}{|l|}{ QP standards included: } \\
\hline Vehicle emissions standards. & $\mathrm{X}$ & $\mathrm{X}$ & $\mathrm{X}$ & $\mathrm{X}$ & $\mathrm{X}$ & $\mathrm{X}$ & $\mathrm{X}$ \\
\hline Vehicle accessibility standards & $\mathrm{X}$ & $\mathrm{X}$ & $\mathrm{X}$ & $\begin{array}{l}\text { Max vehicle age } \\
\text { only }\end{array}$ & $\mathrm{X}$ & $\mathrm{X}$ & $\mathrm{X}$ \\
\hline $\begin{array}{l}\text { Vehicle maintenance and } \\
\text { cleanliness. }\end{array}$ & $\mathrm{X}$ & $\mathrm{X}$ & $\mathrm{X}$ & No & $\mathrm{X}$ & $\mathrm{X}$ & $\mathrm{X}$ \\
\hline $\begin{array}{l}\text { Driver training and customer } \\
\text { service. }\end{array}$ & $\mathrm{X}$ & $x$ & $\mathrm{X}$ & $\mathrm{X}$ & $\mathrm{X}$ & $\mathrm{X}$ & $\mathrm{X}$ \\
\hline Punctuality and reliability & $\mathrm{X}$ & $\mathrm{X}$ & $\mathrm{X}$ & $\mathrm{X}$ & $\mathrm{X}$ & $\mathrm{x}$ & $\mathrm{X}$ \\
\hline Money back guarantee & $\mathrm{X}$ & No & $\mathrm{X}$ & No & No & $\mathrm{X}$ & $\mathrm{X}$ \\
\hline Limit freqcy of service changes & $\mathrm{X}$ & $\mathrm{X}$ & $\mathrm{X}$ & No & $\mathrm{X}$ & $x$ & $\mathrm{X}$ \\
\hline Paper info on/off bus & $\mathrm{X}$ & No & $\mathrm{X}$ & No & No & $\mathrm{X}$ & $\mathrm{X}$ \\
\hline Real time info & $\mathrm{X}$ & $\mathrm{X}$ & $\mathrm{X}$ & No & $\mathrm{X}$ & $\mathrm{X}$ & $\mathrm{X}$ \\
\hline $\begin{array}{l}\text { Infrastructure - stops, shelters and } \\
\text { stations }\end{array}$ & $\mathrm{X}$ & $\mathrm{X}$ & $\mathrm{X}$ & $\mathrm{X}$ & $\mathrm{X}$ & $\mathrm{X}$ & $\mathrm{X}$ \\
\hline Infrastructure - priority lanes & $\mathrm{x}$ & $\mathrm{X}$ & $\mathrm{X}$ & $\mathrm{X}$ & $\mathrm{X}$ & $\mathrm{x}$ & $\mathrm{X}$ \\
\hline Infrastructure - signal priority & $\mathrm{X}$ & $\mathrm{X}$ & $\mathrm{X}$ & No & $\mathrm{X}$ & $\mathrm{X}$ & $\mathrm{X}$ \\
\hline Maintenance of infrastructure & $\mathrm{X}$ & $\mathrm{X}$ & $\mathrm{X}$ & No & No & $\mathrm{X}$ & $\mathrm{X}$ \\
\hline Parking/moving veh enforcement & $\mathrm{X}$ & $\mathrm{X}$ & No & No & No & $\mathrm{X}$ & $\mathrm{X}$ \\
\hline Regulation of fares & No & No & $\mathrm{X}$ & No & $\mathrm{X}$ & No & No \\
\hline Minimum service levels. & No & No & $\mathrm{X}$ & $\mathrm{X}$ & $\mathrm{X}$ & No & No \\
\hline
\end{tabular}

